\title{
Maternal Morbidity in Vaginal Delivery With or Without Episiotomy in Nulliparous Women
}

\author{
Sumana Thapa', Indira Acharya,1 Meeta Singh² and Josie Baral ${ }^{2}$
}

1:Department of Obstetrics and Gynaecology, Nepalese Army Institute of Health Sciences, Shree Birendra Hospital, Chhauni, Kathmandu, Nepal.

2: Department of Obstetrics and Gynaecology, Tribhuvan University Teaching Hospital Kathmandu, Nepal

\section{ABSTRACT}

Introduction: Episiotomy incision is the most common surgical procedure around the globe and in many countries, it has become a routine policy. Episiotomy in all women with vaginal delivery has no benefit. Rate of episiotomy varies widely around the globe, while in Nepal all nulliparous and primiparous hospital deliveries are given routine episiotomy. So, this study aimed to compare the maternal morbidity during first vaginal birth in women with or without episiotomy.

Methods: This is a hospital based randomized prospective comparative study conducted in the Obstetrics and Gynaecology Department of a teaching hospital of Kathmandu, Nepal. The subjects were divided into episiotomy group and no episiotomy group. Under local anaesthesia mediolateral episiotomy was given in the second stage with crowning of the head in episiotomy group. Nature of morbidity seen were recorded in both the groups immediately after delivery, after 6 hours and after 1 week and compared.

Results: In no episiotomy group intact perineum (26.3\%), laceration (10.5\%) and first and second degree spontaneous perineal tear $(63.1 \%)$ were observed. Total perineal surgical repair was performed $81.55 \%$ patients. Intact perineum was high among no episiotomy group. Third degree tear, vulval haematoma, wound gaping and perineal oedema were seen in episiotomy group.

Conclusion: Anterior perineal laceration rate was high in no episiotomy group than episiotomy group but overall few morbidities were present in no episiotomy group in comparison to episiotomy group. So, episiotomy should not be considered to prevent insignificant anterior perineal lacerations.

Keywords: episiotomy; perineal tear; Nepal

Correspondence: Sumana Thapa, Department of Obstetrics and Gynaecology, Nepalese Army Institute of Health Sciences, Shree Birendra Hospital, Chhauni, Kathmandu, Nepal. Email: karkisumana@yahoo.com

To cite this article: Thapa S, Acharya I, Singh M, Baral J. Maternal Morbidity in Vaginal Delivery with or without Episiotomy in Nulliparous Women. Medical Journal of Shree Birendra Hospital. 2017;17(2):41-6.

DOI: http://dx.doi.org/10.3126/mjsbh.v16i2.17713

Conflict of Interest: This manuscript was prepared as part of thesis during doctor of Medicine (MD) of the first author. 


\section{INTRODUCTION}

Perineal trauma during child birth is common and has significant maternal morbidity. It can be spontaneous or after episiotomy during birth process. Episiotomy practice has increased after Pomeroy with the concept "all primigravida should receive an episiotomy to protect the fetal head," then it became routine to shorten second stage of labour and prevent injury to mother and baby. 1,2 These days in the obstetric practice, episiotomy incision is the most common surgical procedure around the globe and in many countries, it became a routine policy. $3-5$

Episiotomy in all women with vaginal delivery has no benefit rather causes unnecessary pain to the mother, complications and prolonged suffering and cost. $^{5}$ Reduced lacerations have put forth as a benefit of episiotomy overlooking an episiotomy, a second-degree tear. Number of studies strongly suggests episiotomy is in fact associated with an increased rate of severe perineal injuries like third or fourth degree tears. ${ }^{2}$

Episiotomy rate varies widely namely, $62 \%$ in US and $30 \%$ in Europe. 6 In our part of the world, especially in Nepal, such type of study and publications is not known and, hence, the exact incidence of episiotomy cannot be quoted. It has been often seen and heard that all nulliparous and primi-parous hospital deliveries are given routine episiotomy in Nepal. So, this study aimed to compare the maternal morbidity during first vaginal birth in women with or without episiotomy.

\section{METHODS}

This was a hospital based randomized prospective comparative study conducted in the Department of Obstetrics and Gynaecology of a teaching hospital of Kathmandu, Nepal for a duration of one year in 2009. Nulliparous women in active stage of labour attending labour unit with singleton pregnancy with cephalic presentation at term (Gestational age 3742 weeks) were included in the study. Multiparous women, mal-presentations and mal-positions, multifetal pregnancy, pregnancy with medical disorder, instrumental deliveries, big baby (Clinically or USG weight $>4 \mathrm{~kg}$ ), preterm and previous perineal surgery cases were excluded. A total of 152 cases who fulfilled the selection criteria were randomly recruited for this study, 76 cases in episiotomy group and 76 cases in no episiotomy group.

Approval from research committee of the institute was taken. A pilot study was conducted in 10 patients to test the feasibility of this study. Modifications were made as per the findings of the pilot study. Details of the study were explained to the patient and only those willing to participate in the study and fulfilling the inclusion criteria were included into the study after taking the informed consent. Delivery was conducted by a single person and cases were examined during and immediately after delivery at the labour room, after six hours in maternity ward and after one week. The morbidities were recorded and compared between the two groups.

A structural questionnaire was used on all the participants, which were filled by the researcher. The collected data were entered in Statistical Package for Social Science (SPSS) and analysis was using Chi-Square test.

\section{RESULTS}

Maximum women were in the age group of 20-29 years in both the groups. The mean age in episiotomy group was $22.88 \pm 3.241$ years and mean age in no episiotomy group was $22.49 \pm$ 2.788 years which was statistically insignificant $(\mathrm{p}=0.422)$. In both groups, most of the parturient 
Table 1: Distribution of Gestational Age.

\begin{tabular}{|c|c|c|c|c|}
\hline $\begin{array}{c}\text { Gestational } \\
\text { Age (weeks) }\end{array}$ & \multicolumn{5}{|c|}{ Group } \\
\hline & \multicolumn{2}{|c|}{ Episiotomy } & \multicolumn{2}{c|}{ No Episiotomy } \\
\hline & Frequency & $\%$ & Frequency & $\%$ \\
\hline$<40$ & 47 & 61.8 & 55 & 72.4 \\
\hline $\mathbf{4 0}$ or more & 29 & 38.2 & 21 & 27.6 \\
\hline Total & 76 & 100.0 & 76 & 100.0 \\
\hline
\end{tabular}

were delivering within the expected date $(<40$ weeks) (Table 1.).

Most of the women were housewives i.e. $68.4 \%$ in each group. Out of 152 cases, majority of women had adequate $(>4) \mathrm{ANC}$ attendance i.e. $78.9 \%$ in episiotomy group and $85.5 \%$ in no episiotomy group. The estimated visible blood loss in episiotomy group was more in no episiotomy group (average blood loss $128.49 \pm 27.797 \mathrm{ml}$ and $96.45 \pm 29.358 \mathrm{ml}$ respectively) and this was statistically significant $(\mathrm{p}<0.001)$.

In no episiotomy group intact perineum was in $26.3 \%$, perineal laceration in $10.5 \%$, spontaneous tear in $63.1 \%$ and total perineal repair was $63.1 \%$. In episiotomy group, there was 1 case of third degree perineal tear due to lack of proper support during delivery (Table 2.).

One patient developed a vulval hematoma, detected after six hours of vaginal delivery with episiotomy. It was evacuated under general anesthesia. Two cases of perineal edema were detected and were managed by peri-light, dressing, analgesics and antibiotics. During one week follow up two cases had episiotomy wound gaping (Table 3.).

\section{DISCUSSION}

Episiotomy is one of the commonest obstetric interventions during child birth. Various studies demonstrate that the routine use of episiotomy should be abandoned and selective (restrictive) use of episiotomy should be adapted. In few countries the trend has declined, but in majority it is still a routine policy especially during first vaginal births. In the present study, various morbidity of episiotomy and no episiotomy group during first viable vaginal birth were studied and compared. In no episiotomy group, spontaneous perineal tear (first and second - degree) rate was $63.1 \%$. Intact perineum was $26.3 \%$ and laceration was $10.5 \%$. In episiotomy group 1 case had third degree perineal tear. From 1976 to $1994^{7}$ the rate of episiotomy for

Table 2: Perineal status immediately after delivery

\begin{tabular}{|c|c|c|c|c|}
\hline \multirow[t]{3}{*}{ Perineal status } & \multicolumn{4}{|c|}{ Group } \\
\hline & \multicolumn{2}{|c|}{ Episiotomy } & \multicolumn{2}{|c|}{ No Episiotomy } \\
\hline & Frequency & $\%$ & Frequency & $\%$ \\
\hline Intact & - & - & 20 & 26.3 \\
\hline Laceration & 4 & 5.26 & 8 & 10.5 \\
\hline First degree tear & - & - & 40 & 52.6 \\
\hline First degree with cervical tear & - & - & 2 & 2.6 \\
\hline Second degree tear & - & - & 6 & 7.9 \\
\hline Third degree tear & 1 & 1.31 & - & - \\
\hline Total & - & - & 76 & 100 \\
\hline
\end{tabular}


Table 3: Complications after 6 hours and 1 week of delivery

\begin{tabular}{|c|c|c|c|c|}
\hline \multirow[t]{3}{*}{ Complications } & \multicolumn{4}{|c|}{ Group } \\
\hline & \multicolumn{2}{|c|}{ Episiotomy } & \multicolumn{2}{|c|}{ No Episiotomy } \\
\hline & Frequency & $\%$ & Frequency & $\%$ \\
\hline Hematoma & 1 & 1.31 & - & - \\
\hline Perineal edema & 2 & 2.63 & - & - \\
\hline Episiotomy gaping & 2 & 2.63 & - & - \\
\hline Total & 5 & 6.57 & - & - \\
\hline
\end{tabular}

spontaneous vaginal deliveries at the University of

California, San Francisco, fell from $86.8 \%$ to $10.4 \%$. In England, there is a dramatic fall of episiotomy rate to $20 \%$ from $50 \%$ in $1980.5^{5}$ In all Swedish labor wards in 1995 the mean incidence of episiotomy in nulliparae was $24.5 \%$, a significant decrease from $33.7 \%$ in 1989.7

In this study, there was no third-degree tear or other complications among no episiotomy group whereas in episiotomy group one third degree tear, one vulval hematoma, two perineal edemas and two episiotomy gaping were reported. Homsi et. al. ${ }^{8}$ reviewed the articles where, the relationship of mediolateral episiotomy to third-degree tear was $1.4 \%$ in contrast to $0.8 \%$ without episiotomy $(p<0.01)$. In the present study, the total intact perineum rate was $26.3 \%$ among no episiotomy group. Various studies had mentioned that the rate of intact perineum increases significantly after reduction of the episiotomy rates.2,8-12 The observed rate of anterior perineal laceration was higher among no episiotomy group. Nearly in agreement with this finding Ecker et. al. ${ }^{13}$ observed up to $40 \%$ insignificant vaginal lacerations when the episiotomy rate was decreased from $93 \%$ to $35 \%$. However, these anterior vaginal lacerations do not need any suturing and are considered to carry a very low incidence of pain or other morbidity.

Among the episiotomy group, in this study, the complication rate was $13.15 \%$. Out of which the vulval hematoma was $1.31 \%$. In contrast to the finding of this study, the Argentine Episiotomy Trial Collaborative Group measured about 4\% vulval hematoma in both the trial groups ${ }^{14}$ whereas the vulval hematoma reported by Rockner et. al. ${ }^{10}$ was very high after episiotomy than without episiotomy (38\% versus 13\%). According to Kelin et. al. ${ }^{10}$ study, the primiparous women cared for by physicians with the lowest episiotomy rates had the lowest rate of 3rd and 4th degree tears (1.9\%); by contrast, the groups of physicians with the highest episiotomy rates sustained 3rd and 4th degree tear of $20.9 \%$. Limitations of this study are small sample size and being purely single centered. So to generate the firm evidence there is requirement of larger and multi centric studies.

\section{CONCLUSION}

Episiotomy is one of the commonest obstetric surgical method. Its use must be limited as the anterior perineal laceration rate is high in no episiotomy group than in episiotomy group, however it did not need any suturing. Other operative complications like hematomas, edema and wound gaping and infection can also occur following episiotomy.

\section{ACKNOWLEDGEMENT}

Authors would like to thank Dr Dhan Bahadur Shrestha for his help during preparation of the manuscript. 


\section{REFERENCES}

1. Permezel M, Walker S, Kyprianou K. Beischer \& MacKay's Obstetrics, Gynaecology and the Newborn. 2nd edition. Canada: Elsevier; p.399-406.

2. Bansal RK, Tan WM, Ecker JL, Bishop JT, Kilpatrick SJ. Is there a benefit to episiotomy at spontaneous vaginal delivery? A natural experiment. Am J Obstet Gynecol. 1996 Oct 31;175(4):897-901.

DOI: https://doi.org/10.1016/S0002-9378(96)80021-4

3. Jones HW, Rock JA. Te Linde's Operative Gynecology. 9th edition. Lippincott Williams \& Wilkins; 2003.p.838-43.

4. Dutta DC. Text Book of Obestetrics. 6th edition. New Central Book Agency; 2004. p567-70.

5. Maduma-Butshe A, Dyall A, Garner P. Routine episiotomy in developing countries: Time to change a harmful practice. BMJ. 1998 Apr 18;316(7139):1179-80.

DOI: https://doi.org/10.1136/bmj.316.7139.1179 PMid:9552989 PMCid: PMC1112977

6. Lede RL, Belizan JM, Carroli G. Is routine use of episiotomy justified?. Am J Obstet Gynecol. 1996 May 31;174(5):1399-402.

DOI: https://doi.org/10.1016/S0002-9378(96)70579-3

7. Röckner G, Fianu-Jonasson A. Changed pattern in the use of episiotomy in Sweden. Br.J Obstet Gynecol. 1999 Feb 1;106(2):95-101.

DOI: https://doi.org/10.1111/j.1471-0528.1999.tb08207.x PMid:10426673

8. Homsi R, Daikoku NH, Littlejohn J, Wheeless Jr CR. Episiotomy: risks of dehiscence and rectovaginal fistula. Obstet Gynecol Surv. 1994 Dec 1;49(12):803-8.

DOI: https://doi.org/10.1097/00006254-199412000-00002 PMid:7885655

9. Henriksen TB, Bek KM, Hedegaard M, Secher NJ. Episiotomy and perineal lesion in spontaneous vaginal deliveries. Br.J Obstet Gynecol. 1992 Dec 1;99(12):950-4. https://doi.org/10.1111/j. 1471-0528.1992.tb13695.x PMid:1477014

10. Woolleg RJ. Benefits and risk of episiotomy: A review of the English language literature since 1980. Part I. Obstet Gynecol Surv. 1995;50(11):806-20.

DOI: https://doi.org/10.1097/00006254-199511000-00020

11. Henriksen TB, Bek KM, Hedegaard M, Secher NJ. Methods and consequences of changes in use of episiotomy. BMJ. 1994 Nov 12;309(6964):1255-8. DOI: https://doi.org/10.1136/bmj.309.6964.1255 PMid: 7888844 PMCid: PMC2541821

12. Reynolds JL. Reducing the frequency of episiotomies through a continuous quality improvement program. CMAJ. 1995 Aug 1;153(3):275. PMid:7614443 PMCid: PMC1487201 
13. Ecker JL, Tan WM, Bansal RK, Bishop JT, Kilpatrick SJ. Is there a benefit to episiotomy at operative vaginal delivery? Observations over ten years in a stable population. Am J Obstet Gynecol. 1997 Feb 28;176(2):411-4.

DOI: https://doi.org/10.1016/S0002-9378(97)70507-6

14. Group AE. Routine vs selective episiotomy: a randomised controlled trial. The Lancet. 1993 Dec 18;342(8886-8887):1517-8.

DOI: https://doi.org/10.1016/S0140-6736(05)80085-6 